


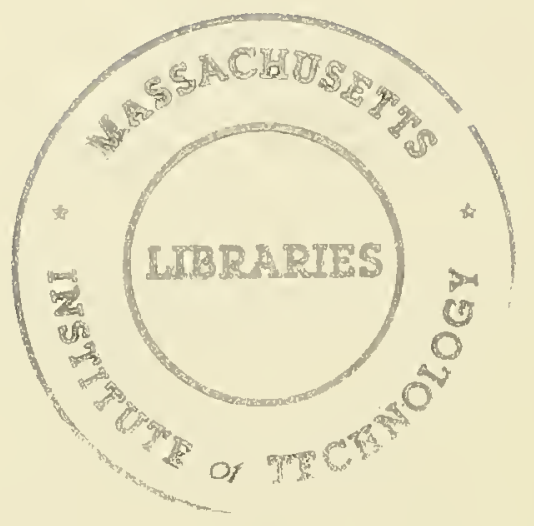


MH LT LIRARIES - DEWEY 
Digitized by the Internet Archive in 2011 with funding from Boston Library Consortium Member Libraries 


\section{working paper}

department

\section{of economics}

\section{EXPORTS AND SUCCESS IN GERMAN MANUFACTURING}

Andrew Bernard Joachim Wagner

$96-10$

April. 1996

\section{massachusetts institute of technology}

50 memorial drive cambridge, mass. 02139 

EXPORTS AND SUCCESS IN GERMAN MANUFACTURING

\section{Andrew Bernard} Joachim Wagner

96-10

April. 1996 
MASSACHISETTS INSTITUTE

OF TECHNOLOGY

JUL 181996

LBRARIES 


\title{
Exports and Success in German Manufacturing*
}

\author{
Andrew B. Bernard ${ }^{\dagger}$ \\ Department of Economics \\ M.I.T. \\ Cambridge, MA 02139
}

\author{
Joachim Wagner \\ Institut für Volkswirtschaftslehre \\ Universität Lüneburg \\ Lüneburg, Germany D-21332
}

April, 1996 v..5

\begin{abstract}
While Germany has a very open, export-oriented manufacturing sector, to date there has been little or no research on the role of exporting in German firm performance. This paper documents the significant differences between exporters and non-exporters and attempts to identify the sources of these disparities. Exporters are much larger, more capital-intensive, and more productive than non-exporters. However, the bulk of the evidence suggests that these performance characteristics predate entry into the export market. We find no positive effects on employment, wage or productivity growth after entry. Our results provide confirming evidence that success leads to exporting, rather than the reverse. KEY WORDS: trade, productivity growth, export-led growth JEL Classification: F10, D21, L60
\end{abstract}

- This research was supported by a grant from the German Ministry of Reseach to the World Economy Laboratory at MIT. Special thanks go to Uwe Rode and the Statistical Office of Lower Saxony for providing access to the data and running the STATA programs. All opinions and errors remain ours alone.

${ }^{\dagger}$ Department of Economics, E52-262c, MIT, Cambridge MA 02139, tel: (617) 253-3488, fax: (617) 253-1330, email: abernardQbernard.mit.edu 


\section{Introduction}

A growing literature on the characteristics and performance of exporters has documented their exceptional performance characteristics at a point in time and has raised the question of whether exporter outperform non-exporters. All the previous work to date has been on countries moving from low shares of exports to shipments to high shares. ${ }^{1}$ In fact, increasing export shares have been held up as a potential source of growth booms for less developed economies, see World Bank (1993). Almost nothing is known about the relationship between exporting and success in advanced economies with stable export shares. It can easily be argued that the German case represents perhaps the best example of an economy with a mature export market. Throughout the post-WWII period, and especially in recent years, Germany has relied on export markets to sustain its manufacturing sector. At least in the business press, it is fairly routine to observe comments about how exporting has allowed Germany to maintain its relatively high share of manufacturing in total output. Since it is well-established that manufacturing jobs are relatively well paid, the relative strength of German manufacturing has supported higher than average wages for German workers.

In this paper, we pursue two goals: first, we examine the characteristics and performance of exporters and non-exporters in German manufacturing. In particular, we document the importance of exporting in both industries and manufacturing establishments. We ask whether exporters pay higher wages and have higher productivity. Second, and perhaps more importantly, we provide evidence on the sources of the relatively good performance traits of exporting firms and plants. We outline and test alternative explanations for the superior performance including those have exporting leading to success and those which argue that successful plants become exporters.

The literature on the relationship between exporting and firm performance is relatively recent. Wagner (1995), using the same data set employed here, documents the positive relation between export participation and firm size. In addition, he reports that total sales growth is positively correlated with increases in export intensity. In a series of papers, Bernard

${ }^{1}$ This includes work on the U.S. where the export share of manufacturing production has been rising rapidly since 1987 (Bernard and Jensen, 1996b). An exception is Wagner (1995) which examines the relationship between firm size and exporting using the Lower Saxony data. 
and Jensen (1995ab, 1996ab) document the differences between exporters and non-exporters in US manufacturing. They find that exporters have substantial size and productivity advantages over non-exporters and pay significantly higher wages. In addition, exporters are more capital and technology intensive. These export premia hold over time and within size category. In explaining the nature of the performance advantage, Bernard and Jensen (1995b) find that good attributes pre-date entry into exporting and that there is less evidence for performance gains once firms have entered the export market. An exception is that export intensive firms have faster productivity growth rates than non-exporters. Bernard (1995) considers the performance of exporting firms during trade liberalization in Mexico, finding that exporters start with performance advantages and outperform non-exporters as liberalization proceeds.

As in these other studies on exporters, we find that exporting plants in Lower Saxony have decidedly better performance attributes than nonexporters, even within the same industry. While wage differentials are modest, productivity is substantial higher at exporters. Turning to an explanation of these finding, our results are quite clear on several points. Several years before they begin to sell their product abroad, exporters already have many of the superior characteristics. They are larger and more productive and these differences are accentuated in the run-up to exporting. The years prior to entry show significantly faster growth in employment, shipments and productivity for these future exporters.

On the other hand, performance after the start of exporting is no better, and often even worse, than that of non-exporters. Especially over short horizons, exporters have lower growth rates for most performance measures. Part of the reason for the poor performance after entry is due to entry and exit in the export market. Entry is associated with dramatic improvements in outcomes including shipments and productivity, while ceasing exporting is a disastrous outcome for the plant, showing negative growth of all measures.

Our results caution that exporting cannot be held up as the panacea for domestic ills. Successful plants and firms can and do take advantage of export markets to grow. However, exporting itself does not provide a performance edge to firms, rather it appears that the ability to position oneself to compete and sell abroad is the source of superior characteristics at exporting plants.

The remainder of the paper is organized as follows: first, in section 2., we review the evidence on how much better exporters are at any point in 
time. We then discuss how exporting might interact with firm structure and performance in section 3.. In section 4., we take up the issue of ex-ante performance and ask whether good firms become exporters. We evaluate ex-post outcomes over various time horizons in section 5 . and assess any performance improvements from exporting. To understand the post-entry results, we look at how plants change when they enter and exit the export market in section 6. and we examine whether exporters have a higher probability of surviving. Section 7. concludes.

\section{Exporters and Exporting}

To understand the role of exporting in success for the establishment, we use an unbalanced panel data set on 7624 German plants from 1978-1992. The strict nature of data confidentiality requirements in Germany means that permission is needed from both the Federal and appropriate State statistical agencies to use information collected at the level of the establishment. As a result, we are limited to studying the export performance from firms in one state, Lower Saxony, the second largest of the 'old' federal states. The data for this paper come from the annual survey of establishments with 20 or more employees conducted by the Lower Saxony statistical office. ${ }^{2}$ Data coverage includes employment, the value of shipments, the value of exports, annual wages by two category of workers, production worker hours, and investment and capital stocks. We start by considering the composition of industry in the panel and export characteristics by sector.

\subsection{Exporting Industries in Lower Saxony}

In Tables 1 and 2, we report the distribution of plants in the Lower Saxony panel by industry for 1978 and $1992 .^{3}$ Among reporting industries, electrical equipment, engineering, and plastics make up the largest share of shipments, while those industries and non-ferrous metals are the largest exporters. In

${ }^{2}$ See Appendix A for more information on construction of the data. Details regarding the data are given in Methner (1992).

${ }^{3}$ For reasons of data confidentiality, we cannot report statistics for some industries in each year. Industries omitted from Tables 1 and 2 cover $28 \%$ of plants and $42 \%$ of employment in the sample in 1979 and $57 \%$ of plants and employment in 1992 . All subsequent calculations in the paper include all plants in the sample. 
both 1979 and 1992, 44\% of all establishments in the panel exported and the average exports to shipments ratio was about $40 \%$ in both years. As might be expected in an export-oriented economy such as Germany, the breadth and depth of exporting is substantial. In particular, it is significantly higher than in a more closed economy such as the U.S., where $13 \%$ of manufacturing plants exported an average of $7.3 \%$ of their output in 1987 (Bernard and Jensen 1995a). ${ }^{4}$ As is typically found in comparisons of exporters to non-exporters, within every industry except coal mining, the average size of exporting plants is substantially larger than that of non-exporters.

\subsection{Exporters and Non-Exporters}

To begin our examination of the differences between exporters and nonexporters in Lower Saxony and the sources of those differences, we show the distribution of export intensity in Figure 1. In our sample, $46 \%$ of plants export in 1978 and 1992. However, even in an export-oriented manufacturing sector, only a small fraction of plants produce the majority of their output for foreign destinations. Half of the plants reported export to shipments ratios of 0.15 or smaller in 1979 and only $12.6 \%$ of plants exporters more than half their output. Exporting intensities are almost identical in 1992, suggesting that while the volume of exports rose, the degree of outward orientation was relatively stable during this period. ${ }^{5}$

We report plant means for a variety of plant characteristics in Tables 3 and 4. We consider 4 groupings of plants by size in both 1978 and 1992: all plants, plants with fewer than 250 employees, plants with more than 250 employees and large plants with more than 500 employees. As reported above, size differentials between exporters and non-exporters are substantial, even within broad size categories exporters are a third to $50 \%$ larger than nonexporters. Shipments are accordingly much larger at exporters as well. In fact, labor productivity, measured in either output per worker or value-added per worker on average is almost identical across exporters and non-exporters. However, this similarity hide substantial variation across plant size. Smaller

\footnotetext{
${ }^{4}$ By 1992 U.S. export participation and intensity had risen significantly; $19 \%$ of U.S. plants exported on average over $13 \%$ of their output. See Bernard and Jensen (1996x).

${ }^{5}$ For Germany as a whole, GDP rose $52.1 \%$ from 1,917 billion DM in 1978 to 2916 billion DM in 1992 (measured in constant 1991 prices). Exports from Germany rose $66.0 \%$ during the same period from $22.7 \%$ of GDP in 1978 to $24.8 \%$ in 1992.
} 
non-exporters are 3-4\% more productive than their exporting counterparts, but large exporters have substantial productivity advantages, on the order of $30-50 \%$.

Looking at labor inputs we again see differences that vary across size categories. Average wages are $7 \%$ higher at exporters but within size categories we see wage premia only at the smaller plants. The average wage differential is driven mostly by the higher numbers of exporters in the large plant categories. As found in other studies, larger plants pay substantially higher wages. Breaking employment into blue collar and white collar workers, we find that any export wage premia are found exclusively for white collar workers. Again small plants appear to pay an export premium to white collar workers but again the heavy presence of exporters among the larger plants who pay substantially more for their white collar workers is the dominant source of the export wage disparities. ${ }^{6}$ In addition the composition of employment differs both across export status and plant size. Exporters employ more white collar workers, especially in the largest plant categories, although the differential has dropped over time.

Surprisingly, exporters are less likely to be part of a multi-plant firm. In the U.S., $60 \%$ of exporting plants are associated with a larger corporate enterprise. In the Lower Saxony region only $22 \%$ of exporters are part of bigger firms, while more than a third of non-exporters had larger corporate structures.

\section{$2.3 \quad$ Export Premia}

The results presented above are broadly consistent with prior work on the differences between exporters and non-exporters in other countries. However, standard trade theory suggests that industry composition may account for the preponderance of these differences. On the other hand, prior research on U.S. and Mexican exports suggests that the differences between exporters and non-exporters within industries are larger than the cross-industry variations. Accordingly, we calculate export premia for the plant characteristics controlling for industry and plant size. The export premia are estimated

${ }^{6}$ The wage-size differential is substantial. Blue collar and white collar workers in exporting plant with $500+$ employees are paid $~ 15 \%$ more than their counterpart in exporting plants with fewer than 250 employees. 
from a regression of the form

$$
\ln X_{i t}=\alpha+\beta \text { Export }_{i t}+\lambda \ln \text { Size }_{i t}+\gamma^{1} \text { Industry }_{i t}+\gamma^{2} \text { Year }_{t}+\epsilon_{i t}
$$

where $X_{i t}$ is the plant characteristic, Export ${ }_{i}$ is a dummy for current export status, Size is given by total employment, and Industry $i$ is a vector of 185 industry dummies and Year $_{t}$ is a vector of year dummies. The export premium, $\beta$, shows the average percentage difference between exporters and non-exporters in the same industry.

We also consider a second specification

$$
\ln X_{i t}=\alpha+\beta \text { Export }_{i t}+\theta \text { EXPTVS }_{i t}+\lambda \ln \text { Size }_{i t}+\gamma \text { Industry }_{i t}+\gamma^{2} \text { Year }_{t}+\epsilon_{i t}(2)
$$

where EXPTVS $_{i}$ is the share of exports in total shipments. This specification allows for an export premium that varies with export intensity.

Results from the two specifications are given in Table 5. As seen above, average wages are slightly higher at exporters, but the difference comes entirely from wages for white collar workers which are $2.3 \%$ higher at exporters, while, interestingly, blue collar workers receive lower wages. The small wage differentials are even more surprising in light of the large productivity differences between exporters and non-exporters. Shipments per worker are 19.4\% higher at exporters and value-added per worker is $21.6 \%$ higher.

Part of the higher productivity is due to increased capital intensity at exporting plants. Within industries exporters are $12.2 \%$ more capital intensive and invest $7.6 \%$ more per worker. The composition of employment differs substantially as well, exporters employ $4.0 \%$ more white collar workers as a fraction of their total work force. Even controlling for industry and plant size, in Lower Saxony, exporters are less likely to be part of a multi-plant establishment.

The relationship between export intensity and plant characteristics is given in column 2 of Table 5 . For all types of wages, there is a positive relationship between export intensity and the wage level. This is particularly true for white collar wages which rise $0.9 \%$ for each $10 \%$ increase in export intensity. Since we have no controls for the human capital of the workers, it is likely that the increasing white collar wage premium is due to higher skill and education levels of workers in exporting firms. ${ }^{\text {? }}$

${ }^{7}$ Wagner (1996) reports evidence from a panel of firms that the share of employees with a university or polytechnic degree is positively correlated with export status and export intensity. 
The productivity rise with export intensification is even stronger. Plants that ship less than $10 \%$ of the product abroad have a productivity advantage of $14-17 \%$ over non-exporters, while plants that ship more than half of their output abroad have productivity premia of $31-34 \%$. This matches the differences in capital intensity and investment per worker, both of which rise sharply as export intensity increases. Similarly the share of white collar workers in total employment increases as export intensity rises. ${ }^{8}$ While the average exporter is less likely to belong to a multi-plant firm, plants with high export shares are increasingly likely to be part of such a firm.

In unreported results, we recalculate the premia dropping the industry controls. Wage premia rise substantially especially for white collar workers. In other words exporters in general receive higher wages but this is mostly an industry effect, exporting industries pay higher wages. This could reflect German wage setting practices whereby significant fractions of wage movements are determined in industry bargaining and firm-specific components are relatively small. Productivity differentials are unchanged (or slightly higher). Capital intensity differentials are actually lower, and insignificant without the industry controls, while investment per worker is unchanged. Similarly the white collar fraction of employment is unchanged when the industry dummies are dropped.

In the previous results we found that wages were slightly higher at exporting plants, particularly for white collar workers. To more properly evaluate the role of exporting in the increased wages, we present results in Table 6 from regressions of the form below:

$$
\begin{aligned}
& \ln \text { Wage }_{i t}=\alpha+\beta^{1} \text { Export }_{i t}+\lambda \ln \text { Plant }_{i t}+\gamma^{1} \text { Industry }_{i t}+\gamma^{2} \text { Year }_{t}+\epsilon_{i t}(3) \\
& \ln \text { Wage }_{i t}=\alpha+\beta^{2} \text { Export }_{i t}+\theta \text { EXPTVS }_{i t}+\lambda \ln \text { Plant }_{i t}+\gamma \text { Industry }_{i t}+\gamma^{2} \text { Year }_{t}+\epsilon_{i t}(4)
\end{aligned}
$$

where Plant ${ }_{i t}$ is a vector of plant characteristics including total employment, capital per worker, production worker hours, and a multi-plant dummy. The wage premia found before are almost unchanged, even though all the plant characteristics enter significantly. The average wage premium at exporters is $2.6 \%$, while blue collar workers receive no premium and white collar workers

\footnotetext{
${ }^{8}$ This result suggests that the increased share of white collar workers is not simply due to the overhead requirements of exporting.
} 
are paid $3.3 \%$ more. Results including export intensity are similar, increasing intensity raises the wages of all workers, especially white collar workers. Excluding the industry dummies we see wage premia on the order of $5-10 \%$, again lowest for blue collar workers and highest for white collar employees.

Finally, to determine the robustness of the wage premia to unobserved heterogeneity across plants, we estimate a fixed effect specification. The magnitude of the export premium for average wages drops to $0.8 \%$ and that for white collar workers drops to $1.3 \%$ but both remain significant. ${ }^{9}$

\section{Exporting and Firm Success}

The previous section documented emphatically that exporters have relatively desirable performance characteristics. In particular, productivity at exporters is substantially higher than at non-exporters. However, the exact relationship between exporting and good firm outcomes is not revealed by the cross-section analysis. In this section, we present several different, but not necessarily mutually exclusive, discussions of how exporting and success night be related at the firm.

\subsection{Exporting Improves Firms}

In discussing the relationship between exporting and firm success in Germany, one hears two familiar phrases: "all German firms are exporters" and "German firms have to export to succeed". The descriptive statistics in the previous section clearly refute the fact that all German firms are exporters but the question remains of whether exporting firms outperform non-exporters. In a survey piece, Richardson and Rindal (1995) outline numerous arguments why exporters might be better firms than non-exporters and make the case for increasing policy attention to the concerns of exporting plants.

There are several theoretical reasons why exporting might improve firm performance. First, in an economy as small as Germany's, exporting provides a natural expansion of the market. Serving a larger market might allow a firm

${ }^{9}$ Considering the coefficients on the other observable plant characteristics, we find that capital deepening is positively related to wages for all types of workers, as is the multi-plant dummy. Increasing size has a negative effect in the fixed effects specification, suggesting that new workers may be paid less than the average wage. 
to take advantage of any economies of scale in production or to provide some reduction in domestic variations in demand. In either case we would expect to see higher output levels at exporting firms as well as a lower probability of failure.

Another link running from exporting to success stems from the more nebulous notion of international competition. The reasoning, often associated with the McKinsey (1993) study of manufacturing, argues that firms participating in international markets are exposed to more intense competition and must improve faster than firms who sell their products domestically and face no international markets. In its purest form, this argument does not require exporting as a domestic-oriented firm can face 'imported' competition. However, we would expect that, on average, exporting firms should outperform non-exporters in terms of sales and productivity growth. An additional implication is that exiting the export market will signal failure and be associated with negative outcomes.

Yet another route for exporting to lead to success focuses on product variety. If firms are not differentiated by cost of production, but rather by product attributes, then those products that are desirable to foreign consumers will be exported. Exporting firms will sell more goods and hire more inputs but might have no relative gain in productivity. Empirical implications of this model include relative employment and output increases when firms begin exporting but no growth advantages in the long run for any characteristic. $^{10}$

\subsection{Good Firms Export}

While there are many reasons why exporting might improve firm performance, the argument for reverse causation is simple and compelling. There is little doubt that there exist additional costs of selling goods in foreign markets. The range of extra costs include transportation costs if the market is distant, distribution or marketing costs, personnel with skill to manage foreign networks or production costs in modifying current domestic products for foreign consumption. Any additional cost of selling abroad has a similar effect, more productive firms will be more likely to export. Similarly,

\footnotetext{
${ }^{10}$ Shipments and input growth might be faster or slower at exporters after entry depending on the relative growth of domestic and foreign markets.
} 
firms with greater monopoly power should export earlier. In either case, the cross-sectional differences between exporters and non-exporters may be easily explained by ex-ante differences between firms. Good firms become exporters.

A related dimension of the success leads to exporting story may result from forward-looking behavior by firms. If firms must lower costs or in troduce new products to successfully export, then improved performance might occur just before entry into the export market. Instead of exporting leading to expost success, the desire to export leads the firm to improve its performance ex-ante.

\section{Performance Before Exporting}

The competing explanations presented in the previous section for the positive correlation between exporting and good plant characteristics provide some simple testable implications. If exporting leads to success, we would expect that today's exporters should outperform today's non-exporters, ceteris paribus. If, on the other hand, firms succeed before they begin exporting, we would expect higher levels and faster growth rates for future entrants into the export market. Nothing about the explanations is mutually exclusive so we might find evidence for both explanations. We start by considering the characteristics of exporter's several years prior to entry into the foreign market.

If good firms become exporters then we should expect to find significant differences in performance measures several years before they begin to export. To verify this possibility, we select a sub-sample of our plants, including only those that did not export for at least three year in a row, i.e. plants that did not export in years $\mathrm{T}-3, \mathrm{~T}-2$, and $\mathrm{T}-1$ but may or may not have exported in year $\mathrm{T}$. We then regress the levels of our performance measures in year $\mathrm{T}-3$ on the export status of the plant in year $\mathrm{T}$.

$$
\ln X_{i T-3}=\alpha+\beta \text { Export }_{i T}+\gamma \text { Industry }_{i}+\kappa \operatorname{Year}_{T-3}+\epsilon_{i T-3}
$$

The results are reported in Table 7 . We find that few of the coefficients on the export dummy in year $\mathrm{T}$ are significant, even at the $10 \%$ level. ${ }^{11}$ However,

${ }^{11}$ The high p-values are mostly being driven by the small number of future exporters relative to future non-exporters. 
the magnitude of the point estimates suggests that exporting establishments do indeed have many of their desirable performance characteristics 3 years prior to entering the export market. Employment is $9 \%$ higher at future exporters, higher for white collar workers, and shipments are $11 \%$ greater. Even productivity is $2-5 \%$ greater at these establishments.

In Table 8 , we provide another check of the relationship between exante success and exporting. We consider the growth performance of future exporters in the years prior to entry, i.e. from year T-3 to T-2 and T-2 to $\mathrm{T}-1$, in a regression of the following form

$$
\Delta \ln X_{i t}=\alpha+\beta \text { Export }_{i T}+\gamma \text { Industry }_{i}+\kappa \text { Year }_{t}+\epsilon_{i t} .
$$

Here,we find emphatic evidence that plants who enter the export market outperform their non-exporting counterparts in the years prior to entry. Employment growth is $1.4 \%$ faster per year and is $2.4 \%$ higher for white collar workers. Shipments grow $2.7 \%$ faster in the years leading up to exporting. Even productivity growth is $1.0-1.6 \%$ higher although the coefficient is not significant. Wage performance is no different at the two types of plants, confirming our earlier results that exporters do not have substantially different wage levels than non-exporters.

On balance, we find evidence that exporters have better performance than non-exporters several years before beginning to export. In addition, these differences are increasing at rapid rates during the run-up to exporting. In the next section, we ask whether this superior performance continues once the plant begins to export.

\section{Performance After Exporting}

To evaluate the possible effects of exporting on plant performance in Germany, we run a simple regression of changes in plant characteristics. As mentioned above, we focus on the results for shipments and productivity to evaluate plant performance in Table 9 . Productivity, employment and wage growth provide indicators of the benefits to the overall economy.

$$
\% \Delta X_{i T}=\frac{1}{T}\left(\ln X_{i T}-\ln X_{i 0}\right)=\alpha+\beta \text { Export }_{i 0}+\delta \text { Plant }_{i 0}+\varepsilon_{i T} .
$$

The results for one year horizons are particularly poor for all characteristics. Wages of all types grow more slowly at exporters than non-exporters, 
$0.4 \%$ per year slower. The coefficient for employment growth is slightly positive although not significant. Shipments growth is substantially lower for exporters, $1.2 \%$ per year less than at non-exporters. This lower growth in output results in dramatically lower productivity growth, exporters see productivity growth 1.5-1.7\% lower than similar non-exporting firms.

Since it is likely that the year of entry into exporting is one of substantial changes for the plant, we also consider exporter performance over a five year horizon. Wages continue to show significantly negative results, especially for blue collar workers. Employment gains for production workers are positive over the long horizon. Perhaps most importantly, productivity growth is still sharply lower for exporters even over the longer interval, averaging $0.7-1.0 \%$ per year less. Results over the longest available horizon in our panel, nine years, show no significant growth differences between exporters today and non-exporters today.

These results are bad news for the theories that exporting by itself improves plant performance. At best there are no significant differences, and for most intervals exporters substantially underperform non-exporters. The most damaging evidence comes from the productivity numbers. We see significantly worse labor productivity growth at exporters. To help us understand the sharp differences in relative performance, in the next section we describe the changes that occur at plants as they enter and exit the export market.

\section{Entry, Exit and Survival}

Thus far, we have shown evidence that exporters outperform non-exporters prior to entry but perform substantially worse after starting to export. In this section, we evaluate the changes that occur during the transition years in and out of exporting. We would expect to find that shipments adjust sharply in the transition years as firms begin supplying a new market, however, other measure such as employment and productivity may or may not adjust during the transition year. We estimate

$$
\Delta \ln X_{i T}=\alpha+\beta_{1} \operatorname{Start}_{i T}+\beta_{2} \operatorname{Both}_{i T}+\beta_{3} \operatorname{Stop}_{i T}+\gamma Z_{i 0}+\varepsilon_{i T}
$$

where $Z_{i 0}$ is a vector of plant characteristics in year 0 , including measures of size, capital intensity, hours, and multi-plant status. The dummies for 
export status are defined as

$$
\begin{aligned}
& \operatorname{Start}_{i T}=1 \text { if }\left(\text { Export }_{i 0}=0\right) *\left(\operatorname{Export}_{i T}=1\right) \\
& \text { Both }_{i T}=1 \text { if }\left(\text { Export }_{i 0}=1\right) *\left(\operatorname{Export}_{i T}=1\right) \\
& \text { Stop }_{i T}=1 \text { if }\left(\text { Export }_{i 0}=1\right) *\left(\text { Export }_{i T}=0\right)
\end{aligned}
$$

where non-exporting in both years is the reference category. The coefficients, $\beta_{1}, \beta_{2}$, and $\beta_{3}$, give the increase in growth rates for entrants, exporters in both years, and exits relative to non-exporters in both years.

The results are reported in Table 10. For almost every measure, plants entering the export market have substantially faster growth. Conversely, exiting plants suffer terrible outcomes by every measure. and Employment grows strongly at plants entering the export market (4.2\%) but plants that exit show even larger drops $(-11.6 \%)$ while continuing exporters increase employment $1.6 \%$ faster than non-exporters. The employment changes are more pronounced for white collar workers than blue collars employees. Firms entering the export market increase their white collar employment $6.1 \%$ and drop it $9.7 \%$ when they exit. The comparable adjustments for blue collar workers are $3.1 \%$ and $-5.8 \%$ respectively. Wages increase at starters $(0.8 \%)$ and fall sharply at stoppers $(-1.6 \%)$. surprisingly continuing exporters see worse wage performance than non-exporters.

Not surprisingly, we find a large change in total shipments as plants enter and exit. Entrants increase shipments $10.2 \%$ while exits see their shipments fall $12.9 \%$. Productivity shows similar patterns rising $4.8-6.7 \%$ in the year that exports begin and falling $3.6-8.4 \%$ in the year exports cease.

Comparing plants that do not change status, we find mixed results. Continuing exporters see larger growth in employment, and somewhat faster shipments growth. However, productivity and production worker wages grow more slowly than at non-exporters in both periods.

\subsection{Survival}

For our final exploration of the exporting-success nexus, we consider perhaps the most important potential benefit, the impact of exporting on the probability of plant survival. Since one of the most important advantages to the firm from exporting may be the diversification of risk associated with demand shocks, we examine the relationship between exporting and plant 
survival. Table 11 presents the results from a probit of the form

$$
F_{i t}=\left\{\begin{array}{lc}
1 & \text { if } \beta \text { Export }_{i t-1}++\lambda Z_{i t-1}+\gamma \text { Year }_{t-1}+\varepsilon_{i t}>0 \\
0 & \text { otherwise }
\end{array}\right.
$$

where $F_{i t}$ equals one of the plant fails in year t. As before $Z_{i t-1}$ is a vector of plant characteristics in the initial year. We look at failure probabilities over one, five and nine year intervals and consider specifications with and without plant characteristics in the initial year. Excluding plant characteristics, we find a strong increase in the probability of survival associated with exporting. The probability of failure is $3 \%$ lower over one year horizon, $10 \%$ lower over a five year interval and almost $15 \%$ lower nine years out. However, when we control for other observable characteristics of the plant, including size, productivity, and employment, the coefficient on export status, while still negative, is close to zero and insignificant.

\section{Conclusions}

This paper has documented important performance advantages at exporting establishments in Germany. As in other countries, comparing plants within an industry, we find that exporters in German are substantially larger, more capital intensive, employ more white collar workers, and are substantially more productive than non-exporters. The productivity advantage of 15-20\% for exporters is of particular interest. If participation in foreign markets leads to substantial productivity gains for firms, then there are important consequences for policy and long run economic performance.

To understand the nature of the correlation between exporting and good performance, we propose several alternative explanations. Exporting may lead to successful outcomes if competition in international markets is more intense than in the German domestic market. On the other hand, there are numerous reasons to believe that good firms self-select into the export market.

In providing empirical evidence on these alternatives, we find the results to be quite clear. Good firms most certainly become exporters. Most, if not all, the productive advantages are present three years before entry into exporting. In addition, growth rates of employment, shipments and productivity are faster in the years leading up to exporting. There is little or 
no evidence that exporting by itself enhances performance. While exporters do show higher survival rates unconditionally over various time horizons, these can be easily explained by the superior performance characteristics of exporting plants ex-ante.

While shipments, wages and productivity do not grow faster after entry in to the export market, we do find that plants undergo substantial changes during the years they enter or exit. In particular, growth rates for new exporters are significantly higher than non-entrants in almost every category. Growth rate advantages for employment, shipments and productivity are $4 \%$, $10 \%$, and $5 \%$ respectively. Plants that stop selling abroad see more than comparable decreases in performance.

Our findings demonstrate that firms must succeed in order to begin exporting. The transition from producing solely for the domestic market to selling abroad involves dramatic changes for the firm including rapid growth of employment and output and sharp increases in productivity. 


\section{Appendix: Data}

The data employed in this study are establishment level data from manufacturing industries in the one of the 'old' German Federal States (Laender), Lower Saxony (Niedersachsen). They were collected in the regular surveys by the Statistical Office (Niedersaechsisches Landesamt fuer Statistik - NLS). The coverage of the surveys is all establishments from manufacturing industries that employ at least 20 persons in the local production unit or in the company that owns the unit. For details on coverage in specific industries see Methner (1992).

Using the establishment identification code, we matched surveys from 1978 through 1992 to form an unbalanced panel. Annual data is available on: industry, blue collar hours, blue collar workers, sum of annual gross wages, sum of annual gross salaries, total employment (average from monthly reports), blue collar employment (average from monthly reports), sales in Germany, sales outside of Germany, investment (in machinery, in land with/without buildings), payments for rents and leasing, value of production.

All monetary values are reported in current prices. To compute real values, wages and salaries were deflated using the consumer price index (Preisindex fuer die Lebenshaltung, Frueheres Bundesbegeit, Gesamtlebenshaltung). Sales and value of production were deflated using the price index of production at the two digit SYPRO industry level (Index der Erzeugerpreise gewerblicher Produkte) and investments in machinery were deflated using the price index for machinery goods (Preisentwicklung nach den Volkswirtschaftlichen Gesamtrechnungen, Frueheres Bundesbegeit, Anlageinvestitionen / Ausruestungen).

Capital stocks for establishments were calculated from real investment in machinery using a perpetual inventory method with an $18 \%$ depreciation rate. After construction of the capital stocks we are left with data for 19831992. 


\section{References}

Bernard, Andrew B. (1995). "Exporters and Trade Liberalization in Mexico: Production Structure and Performance." MIT Mimeo.

Bernard, Andrew B. and J. Bradford Jensen. (1995a). "Exporters, Jobs, and Wages in U.S. Manufacturing, 1976-1987." Brookings Papers on Economic Activity, Microeconomics. Washington DC.

Bernard, Andrew B. and J. Bradford Jensen. (1995). "Exceptional Exporter Performance: Cause, Effect or Both?." MIT mimeo.

Bernard, Andrew B. and J. Bradford Jensen. (1996a). "Exporters, SkillUpgrading, and the Wage Gap." Journal of International Economics forthcoming.

Bernard, Andrew B. and J. Bradford Jensen. (1996b). "Understanding the U.S. Export Boom." MIT mimeo.

McKinsey Global Institute. (1993). Manufacturing Productivity. Washington, DC. McKinsey and Company Inc.

Methner, Eckart. (1992). "Das Erhebungsprogramm der amtlichen Statistik im Bereich des Produzierenden Gewerbes" in Rainer Ertel und Joachim Wagner (Eds.), Produzieren in Niedersachsen. Empirische Untersuchungen mit Betriebsdaten, Hannover: NIW.

Richardson, J. David, and Karin Rindal. (1995). Why Exports Really Matter! The Institute for International Economics and the Manufacturing Institute, Washington D.C.

Wagner, Joachim. (1995). "Exports, Firm Size and Firm Dynamics." Small Business Economics 7: 29-39.

Wagner, Joachim. (1996). "Export Performance, Human Capital, and Product Innovation in Germany." Jahrbuch fuer Wirtschaftswissenschaften forthcoming.

World Bank. (1993). The East Asian Miracle: Economic Growth and Public Policy. Oxford University Press for the World Bank, Washington D.C. 
Table 1: Industry Characteristics - 1979

\begin{tabular}{|c|c|c|c|c|c|}
\hline Industry & \# of plants & \% Exporters & Exporter size & $\begin{array}{l}\text { Plant Exports } \\
\text { /Shipments }\end{array}$ & $\begin{array}{l}\text { Non- } \\
\text { exporter } \\
\text { size }\end{array}$ \\
\hline Coal Mining & 100 & 43.0 & 123 & 39.9 & $9 \quad 140$ \\
\hline Stone, sand, clay, asbestos & 476 & 17.4 & 93 & 23.2 & 23 \\
\hline Non-ferrous metal & 14 & 87.7 & 663 & 40.1 & 16 \\
\hline Steel drawing, rolling & 92 & 44.6 & 174 & 15.9 & 48 \\
\hline Steel & 168 & 28.6 & 199 & 22.7 & 71 \\
\hline Engineering & 465 & 69.2 & 163 & 47.6 & 65 \\
\hline Shipbuilding & 28 & 71.4 & 329 & 58.9 & 225 \\
\hline Electrical Equipment & 270 & 48.1 & 354 & 37.0 & 165 \\
\hline Optics, watches, clocks & 151 & 30.5 & 187 & 52.6 & 34 \\
\hline Metal products & 133 & 58.6 & 184 & 25.0 & 53 \\
\hline Musical instruments & 27 & 74.1 & 159 & 26.7 & 49 \\
\hline Glass & 31 & 74.2 & 292 & 33.9 & 50 \\
\hline Sawmills & 115 & 35.7 & 85 & 22.3 & 24 \\
\hline Wood processing & 213 & 50.7 & 119 & 17.8 & 42 \\
\hline Cellulose, paper and board & 19 & 89.5 & 332 & 46.4 & 76 \\
\hline Paper and Board & 85 & 67.1 & 141 & 13.8 & 90 \\
\hline Printing & 175 & 45.1 & 74 & 8.1 & 77 \\
\hline Plastics & 200 & 70.0 & 179 & 28.3 & 67 \\
\hline Rubber & 46 & 71.7 & 213 & 36.6 & 841 \\
\hline Leather & 13 & 84.6 & 145 & 18.7 & 42 \\
\hline Textiles & 78 & 73.1 & 252 & 30.5 & 59 \\
\hline Clothing & 191 & 33.5 & 122 & 22.9 & 68 \\
\hline All & 4323 & 44.2 & 259 & 40.7 & 67 \\
\hline
\end{tabular}


Table 2: Industry Characteristics - 1992

\begin{tabular}{|c|c|c|c|c|c|}
\hline Industry & \# of plants & $\begin{array}{l}\% \\
\text { Exporters }\end{array}$ & $\begin{array}{l}\text { Exporter } \\
\text { size }\end{array}$ & $\begin{array}{l}\text { Plant } \\
\text { Exports/Sh } \\
\text { ipments }\end{array}$ & $\begin{array}{l}\text { Non- } \\
\text { exporter } \\
\text { size } \\
\end{array}$ \\
\hline Coal Mining & 104 & 45.2 & 132 & 34.7 & 147 \\
\hline Stone, sand, clay, asbestos & 471 & 15.7 & 99 & 22.3 & 22 \\
\hline Foundries & 34 & 50.0 & 229 & 15.6 & 44 \\
\hline Engineering & 461 & 68.5 & 161 & 46.8 & 65 \\
\hline Electrical Equipment & 277 & 48.0 & 329 & 34.0 & 152 \\
\hline Musical instruments & 24 & 83.3 & 154 & 24.9 & 51 \\
\hline Glass & 33 & 72.7 & 275 & 32.4 & 44 \\
\hline Sawmills & 112 & 35.7 & 90 & 21.5 & 22 \\
\hline Wood processing & 207 & 49.3 & 118 & 17.9 & 40 \\
\hline Cellulose, paper and board & 19 & 89.5 & 322 & 47.6 & 75 \\
\hline Paper and Board & 85 & 62.4 & 155 & 14.3 & 73 \\
\hline Printing & 177 & 39.0 & 77 & 13.8 & 70 \\
\hline Plastics & 193 & 71.5 & 173 & 27.5 & 67 \\
\hline Leather & 15 & 86.7 & 130 & 15.7 & 42 \\
\hline Textiles & 84 & 75.0 & 241 & 30.7 & 56 \\
\hline Clothing & 190 & 33.2 & 118 & 22.6 & 68 \\
\hline All & 4329 & 44.0 & 257 & 39.3 & 66 \\
\hline
\end{tabular}


Figure 1: Distribution of Exporting Plants by Export Intensity - 1992

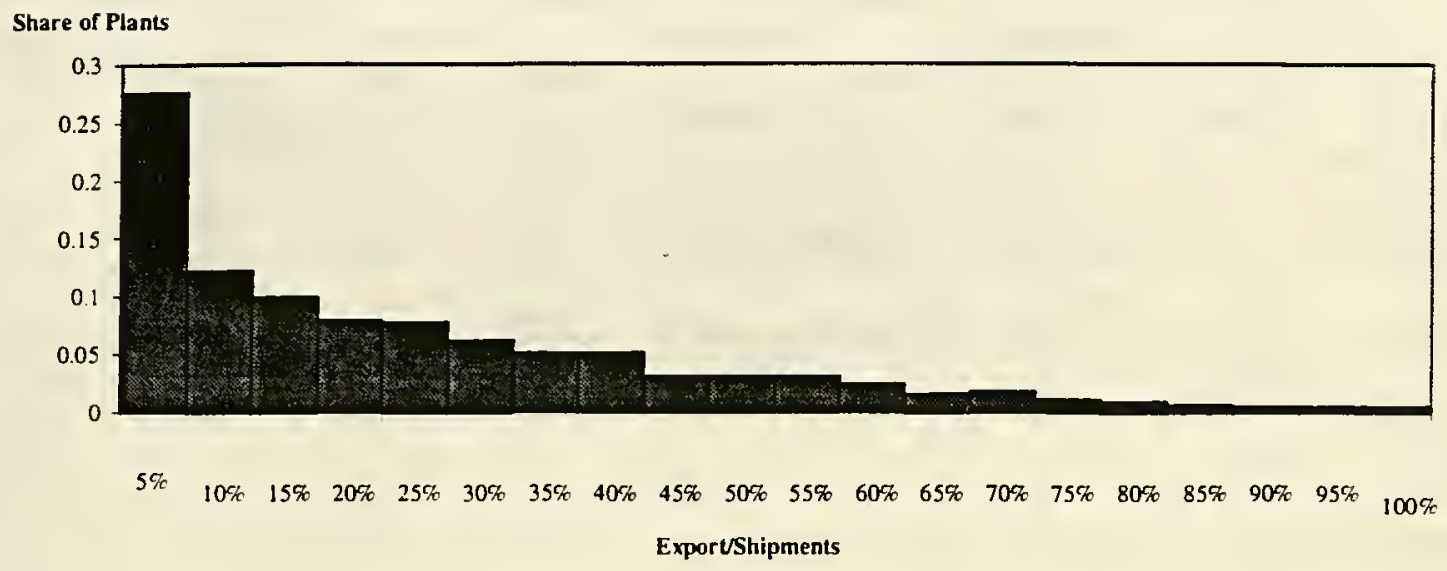


Table 3: Mean Characteristics for Exporters and Non-exporters - 1978

\begin{tabular}{|c|c|c|c|c|c|c|c|c|}
\hline & \multirow{2}{*}{ All Plants } & \multirow{2}{*}{$\begin{array}{l}\text { Non- } \\
\text { Exporters }\end{array}$} & \multicolumn{2}{|c|}{ Less than 250} & \multicolumn{2}{|c|}{ More than 250} & \multicolumn{2}{|c|}{ More than 500} \\
\hline & & & Exporters & $\begin{array}{l}\text { Non- } \\
\text { Exporters }\end{array}$ & Exporters & $\begin{array}{l}\text { Non- } \\
\text { Exporters }\end{array}$ & Exporters & $\begin{array}{l}\text { Non- } \\
\text { Exporters }\end{array}$ \\
\hline Employment & 259.2 & 68.45 & 80.24 & 46.73 & 1000.68 & 629.25 & 1768.56 & 1168.94 \\
\hline Shipments & 76025.6 & 13065.1 & 19287.2 & 10228.7 & 311106 & 86297.2 & 576449 & 113843 \\
\hline Wage per worker & 41.2 & 38.17 & 40.18 & 37.89 & 45.46 & 45.57 & 46.64 & 47.01 \\
\hline Production wage & 35.96 & 35.09 & 35.15 & 34.91 & 39.31 & 39.66 & 40.35 & 39.32 \\
\hline $\begin{array}{l}\text { Non-production } \\
\text { wage }\end{array}$ & 55.87 & 50.73 & 54.63 & 50.3 & 60.98 & 61.48 & 65.58 & 62.33 \\
\hline $\begin{array}{l}\text { Shipments per } \\
\text { worker }\end{array}$ & 237.08 & 237.41 & 232.1 & 239.8 & 257.71 & 175.74 & 267.74 & 115.68 \\
\hline $\begin{array}{l}\text { Value added per } \\
\text { worker }\end{array}$ & 201.26 & 200.76 & 196.12 & 203.19 & 222.56 & 138.24 & 225.1 & 105.3 \\
\hline $\begin{array}{l}\text { Machinery } \\
\text { Invest- ment per } \\
\text { worker }\end{array}$ & 8.2 & 9.47 & 7.71 & 9.31 & 10.23 & 13.45 & 12.09 & 6.71 \\
\hline $\begin{array}{l}\text { Total Invest- } \\
\text { ment per worker }\end{array}$ & 10.37 & 11.29 & 9.94 & 11.13 & 12.18 & 15.38 & 13.96 & 8.08 \\
\hline $\begin{array}{l}\text { Non-production/ } \\
\text { total workers }\end{array}$ & 28.96 & 28.37 & 28.88 & 28.36 & 29.25 & 28.45 & 38.93 & 30.16 \\
\hline Multi-plant & 21.72 & 34.29 & 15.65 & 32.7 & 46.9 & 76.14 & 62.35 & 93.55 \\
\hline \# of plants & 1903 & 2360 & 1533 & 2272 & 370 & 88 & 169 & 31 \\
\hline
\end{tabular}


Table 4: Mean Characteristics for Exporters and Non-exporters 1992

\begin{tabular}{|c|c|c|c|c|c|c|c|c|}
\hline & \multirow{2}{*}{$\frac{\text { All Plants }}{\text { Exporters }}$} & \multirow{2}{*}{$\begin{array}{l}\text { Non- } \\
\text { Exporters }\end{array}$} & \multicolumn{2}{|c|}{$\underline{\text { Less than } 250}$} & \multicolumn{2}{|c|}{ More than 250} & \multicolumn{2}{|c|}{ More than 500} \\
\hline & & & Exporters & $\begin{array}{l}\text { Non- } \\
\text { Exporters }\end{array}$ & Exporters & $\begin{array}{l}\text { Non- } \\
\text { Exporters }\end{array}$ & Exporters & $\begin{array}{l}\text { Non- } \\
\text { Exporters }\end{array}$ \\
\hline Employment & 257.92 & 67.22 & 78.64 & 45.75 & 976.46 & 625.69 & 1792.01 & 1165.71 \\
\hline Shipments & 70008.6 & 11930.1 & 17951.5 & 9317.68 & 278650 & 79883.3 & 533857 & 90878.1 \\
\hline Wage per worker & 40.07 & 37.26 & 39 & 36.97 & 44.32 & 44.93 & 46.08 & 46.99 \\
\hline Production wage & 34.97 & 34.16 & 34.12 & 33.97 & 38.38 & 39.02 & 39.72 & 39.82 \\
\hline Non-production wage & 53.63 & 49.33 & 52.32 & 48.93 & 58.88 & 59.3 & 61.08 & 62.75 \\
\hline Shipments per worker & 227.78 & 225.43 & 22411 & 227.43 & 242.49 & 173.63 & 248.7 & 87.13 \\
\hline Value added per worker & 194.6 & 197 & 190.84 & 199.81 & 209.66 & 123.79 & 205.18 & 81.76 \\
\hline $\begin{array}{l}\text { Machinery Investment } \\
\text { per worker }\end{array}$ & 7.63 & 8.19 & 7.29 & 7.94 & 8.99 & 14.55 & 9.57 & 7.13 \\
\hline $\begin{array}{l}\text { Total Investment per } \\
\text { worker }\end{array}$ & 9.57 & 9.94 & 9.24 & 9.65 & 10.87 & 17.54 & 10.98 & 8.39 \\
\hline $\begin{array}{l}\text { Non-production/total } \\
\text { workers }\end{array}$ & 29.24 & 28.28 & 29.19 & 28.23 & 28.41 & 29.39 & 30.17 & 28.03 \\
\hline Multi-plant & 22.37 & 34.76 & 16.33 & 33.12 & 46.7 & 78.41 & 64.85 & 96.77 \\
\hline \# of plants & 1893 & 2377 & 1515 & 2289 & 378 & 88 & 164 & 31 \\
\hline
\end{tabular}


Table 5: Exporter Premia - Plant Characteristics

\begin{tabular}{|c|c|c|c|c|c|c|c|c|}
\hline & Exporter & t-stat & $\mathrm{R}^{2}$ & Exporter & t-stat & Export share & t-stat & $\mathrm{R}^{2}$ \\
\hline Wage per employee & 0.0169 & $(1.79)$ & 0.465 & 0.0135 & $(1.29)$ & 0.0813 & $(3.46)$ & 0.479 \\
\hline Production Wage & -0.0178 & $(1.73)$ & 0.425 & -0.0182 & $(1.65)$ & 0.0454 & $(1.78)$ & 0.440 \\
\hline $\begin{array}{l}\text { Non-Production } \\
\text { Wage }\end{array}$ & 0.0232 & $(2.28)$ & 0.282 & 0.0171 & $(1.39)$ & 0.0881 & (3.12) & 0.282 \\
\hline $\begin{array}{l}\text { Shipments per } \\
\text { worker }\end{array}$ & 0.194 & $(5.00)$ & 0.423 & 0.1414 & $(3.61)$ & 0.3304 & $(5.78)$ & 0.426 \\
\hline $\begin{array}{l}\text { Value-Added per } \\
\text { worker }\end{array}$ & 0.2163 & $(6.81)$ & 0.338 & 0.1371 & $(4.69)$ & 0.4159 & $(6.05)$ & 0.353 \\
\hline Capital per Worker & 0.1223 & $(4.69)$ & 0.37 & 0.047 & $(1.80)$ & 0.3914 & $(3.57)$ & 0.378 \\
\hline $\begin{array}{l}\text { Machinery Invest- } \\
\text { ment per worker }\end{array}$ & 0.076 & $(2.23)$ & 0.233 & 0.0121 & $(0.40)$ & 0.3355 & $(3.02)$ & 0.234 \\
\hline $\begin{array}{l}\text { Non-Production/ } \\
\text { Total Employment }\end{array}$ & 0.0402 & $(4.68)$ & 0.223 & 0.0332 & $(4.02)$ & 0.049 & $(2.77)$ & 0.240 \\
\hline Shipments & 0.9573 & (13.89) & 0.392 & 0.6721 & $(9.73)$ & 1.6093 & $(10.52)$ & 0.412 \\
\hline Employment & 0.7175 & (14.15) & 0.400 & 0.5099 & $(10.10)$ & 1.2287 & $(9.05)$ & 0.437 \\
\hline Multi & -0.1307 & $(6.72)$ & 0.246 & -0.0867 & $(5.53)$ & 0.1209 & $(2.71)$ & 0.249 \\
\hline
\end{tabular}


Table 6: Exporter Wage Premia

\begin{tabular}{|c|c|c|c|c|c|c|c|c|c|}
\hline \multirow[b]{2}{*}{ Exporter } & All & \multicolumn{2}{|c|}{ Production } & \multirow{2}{*}{$\frac{\begin{array}{c}\text { Non- } \\
\text { production }\end{array}}{0.0329(3.18)}$} & \multicolumn{2}{|c|}{ All } & Production & \multicolumn{2}{|c|}{ Non-Producti } \\
\hline & $0.0259(2.91)$ & -0.0070 & $(0.80)$ & & 0.0187 & $(2.00)$ & $-0.0108-(1.17)$ & 0.0214 & $(1.74)$ \\
\hline Export share & & & & & 0.0608 & $(2.81)$ & $0.0350 \quad(1.54)$ & 0.0712 & (2.50) \\
\hline Employment & $0.0477(13.31)$ & 0.0478 & $(12.81)$ & $0.0485(7.44)$ & 0.0461 & $(12.65)$ & $0.0482(12.01)$ & 0.0475 & (6.56) \\
\hline Capital per worker & $0.0390(9.46)$ & 0.0351 & $(9.97)$ & $0.0495(8.30)$ & 0.0406 & $(9.82)$ & $0.0361 \quad(9.73)$ & 0.0507 & $(8.03)$ \\
\hline Production hours/worker & $0.3892(14.93)$ & 0.5531 & $(18.68)$ & $0.0243(0.77)$ & 0.3873 & $(14.83)$ & $0.5420(18.31)$ & 0.0225 & $(0.69)$ \\
\hline Multi-plant & $0.0934(8.72)$ & 0.0962 & $(9.19)$ & $0.1023(7.03)$ & 0.0890 & $(8.14)$ & $0.0912 \quad(8.43)$ & 0.1013 & $(6.80)$ \\
\hline \multicolumn{10}{|l|}{ Fixed Effects Regressions } \\
\hline Exporter & $0.0087(3.25)$ & -0.0007 & $(0.27)$ & $0.0136(2.39)$ & 0.0081 & $(2.91)$ & $-0.0007 \quad(0.24)$ & 0.0102 & (1.70) \\
\hline Export & & & & & 0.0070 & $(0.76)$ & $-0.0058 \quad(0.58)$ & 0.0109 & $(0.54)$ \\
\hline Employment & $-0.0300(12.33)$ & -0.0078 & $(2.99)$ & $-0.0178(3.33)$ & -0.0389 & $(15.37)$ & $-0.0165 \quad(6.03)$ & -0.0237 & $(4.22)$ \\
\hline Capital per worker & $0.0189(15.34)$ & 0.0169 & $(12.77)$ & $0.0174(6.55)$ & 0.0191 & $(15.46)$ & $0.0172(12.89)$ & 0.0189 & $(6.92)$ \\
\hline Production hours/worker & $0.3082(69.80)$ & 0.4981 & $(104.82)$ & $-0.0793(8.28)$ & 0.2948 & $(65.82)$ & $0.4786(98.90)$ & -0.0845 & (8.55) \\
\hline Multi-plant & $-0.0082(2.13)$ & -0.0012 & $(0.31)$ & $0.0145(1.78)$ & -0.0077 & $(2.01)$ & $-0.0013 \quad(0.32)$ & 0.0185 & (2.23) \\
\hline
\end{tabular}


Table 7: Plant Characteristics Prior to Exporting

\begin{tabular}{l|rc} 
& Exporter & t-stat \\
\hline Employment & 0.0971 & $(1.57)$ \\
Production Workers & 0.0931 & $(1.49)$ \\
Non-Production Workers & 0.1117 & $(1.78)$ \\
Shipments & 0.1124 & $(1.62)$ \\
Shipments per worker & 0.0206 & $(0.57)$ \\
Value-Added per worker & 0.0502 & $(1.07)$ \\
Non-Production/Total Employment & 0.0008 & $(0.12)$ \\
Wage per employee & 0.0018 & $(0.14)$ \\
Production Wage & -0.0149 & $(1.14)$ \\
Non-Production Wage & 0.0253 & $(0.95)$
\end{tabular}


Table 8: Growth Rates Prior to Exporting

\begin{tabular}{l|rc} 
& Exporter & t-stat \\
\hline Employment & 0.0135 & $(2.74)$ \\
Production Workers & 0.0126 & $(2.40)$ \\
Non-Production Workers & 0.0242 & $(3.30)$ \\
Shipments & 0.0273 & $(2.55)$ \\
Shipments per worker & 0.0158 & $(1.52)$ \\
Value-Added per worker & 0.0096 & $(0.78)$ \\
Non-Production/Total Employment & 0.0007 & $(0.56)$ \\
Wage per employee & -0.0003 & $(0.09)$ \\
Production Wage & -0.0032 & $(0.89)$ \\
Non-Production Wage & 0.0024 & $(0.31)$
\end{tabular}


Table 9: Exporter Performance - Various Horizons

\begin{tabular}{|c|c|c|c|}
\hline & One year & Five Year & Nine Year \\
\hline & Exporter t-stat & Exporter t-stat & Exporter t-stat \\
\hline Wage per employee & $-0.0047(3.70)$ & $-0.0098(2.45)$ & $-0.0086(1.00)$ \\
\hline Production Wage & $-0.0035(2.26)$ & $-0.0109(2.20)$ & $-0.0079(0.86)$ \\
\hline Non-Production Wage & $-0.0044(2.08)$ & $-0.0070(0.98)$ & $-0.0206(1.21)$ \\
\hline Employment & $0.0020(0.06)$ & $0.0170(1.20)$ & $0.0031(0.14)$ \\
\hline Production Workers & $0.0048 \quad(1.59)$ & $0.0280(1.93)$ & $0.0067(0.29)$ \\
\hline Non-Production Workers & $-0.0002(0.07)$ & $-0.0026(0.17)$ & $0.0088(0.30)$ \\
\hline Shipments & $-0.0127(2.92)$ & $0.0226(1.25)$ & $-0.0348(0.99)$ \\
\hline Shipments per worker & $-0.0174(5.28)$ & $-0.0510(3.53)$ & $-0.0488(1.88)$ \\
\hline Value-Added per worker & $-0.0159(2.91)$ & $-0.0373(2.50)$ & $-0.0379(1.68)$ \\
\hline $\begin{array}{l}\text { Non-Production/Total } \\
\text { Employment }\end{array}$ & $0.0005(0.88)$ & $-0.0028(1.34)$ & $0.0046(1.09)$ \\
\hline
\end{tabular}


Table 10: One Year Performance by Export Status (Starters, Stoppers, Both)

\begin{tabular}{l|rrrrrr} 
& Start & t-stat & Stop & t-stat & Both & t-stat \\
\hline Employment & 0.0421 & $(5.13)$ & -0.1157 & $(5.04)$ & 0.0162 & $(4.97)$ \\
Production Workers & 0.0312 & $(3.19)$ & -0.0579 & $(4.46)$ & 0.0128 & $(4.00)$ \\
Non-Production Workers & 0.0610 & $(6.13)$ & -0.0974 & $(4.76)$ & 0.0136 & $(3.69)$ \\
Shipments & 0.1015 & $(5.13)$ & -0.1286 & $(6.22)$ & 0.0068 & $(1.61)$ \\
Shipments per worker & 0.0669 & $(3.62)$ & -0.0839 & $(5.44)$ & -0.0054 & $(1.72)$ \\
Value-Added per worker & 0.0483 & $(2.94)$ & -0.0359 & $(1.85)$ & -0.0100 & $(1.97)$ \\
Wage per employee & 0.0078 & $(2.44)$ & -0.0160 & $(2.32)$ & -0.0031 & $(2.37)$ \\
Production Wage & 0.0052 & $(1.28)$ & -0.0007 & $(0.12)$ & -0.0035 & $(2.08)$ \\
Non-Production Wage & 0.0096 & $(1.01)$ & -0.0289 & $(2.72)$ & -0.0014 & $(0.77)$ \\
Non-Production/Total & 0.0047 & $(2.40)$ & 0.0115 & $(2.94)$ & -0.0001 & $(0.17)$ \\
Employment & & & & & &
\end{tabular}


Table 11: Probability of Plant Failure

\begin{tabular}{|c|c|c|c|c|}
\hline & \multicolumn{2}{|c|}{ One Year } & \multicolumn{2}{|c|}{ Nine Year } \\
\hline Exporter & $\begin{array}{l}-0.0342 \\
(15.77)\end{array}$ & $\begin{array}{c}-0.0002 \\
(0.17)\end{array}$ & $\begin{array}{r}-0.1477 \\
(10.33)\end{array}$ & $\begin{array}{c}-0.0127 \\
(0.75)\end{array}$ \\
\hline Employment & & $\begin{array}{c}-0.0174 \\
(20.51)\end{array}$ & & $\begin{array}{r}-0.1199 \\
(14.37)\end{array}$ \\
\hline Value-added per worker & & $\begin{array}{l}-0.008 \\
(10.97)\end{array}$ & & $\begin{array}{c}-0.0575 \\
(6.18)\end{array}$ \\
\hline Capital per worker & & $\begin{array}{c}-0.0052 \\
(9.61)\end{array}$ & & $\begin{array}{c}-0.0443 \\
(6.72)\end{array}$ \\
\hline Hours per production worker & & $\begin{array}{c}-0.0183 \\
(6.00)\end{array}$ & & $\begin{array}{l}-0.184 \\
(5.05)\end{array}$ \\
\hline Multi-plant & & $\begin{array}{c}-0.0041 \\
(2.57)\end{array}$ & & $\begin{array}{l}0.0163 \\
(0.99)\end{array}$ \\
\hline White collar/total employment & & $\begin{array}{l}0.0186 \\
(4.51)\end{array}$ & & $\begin{array}{c}0.0338 \\
(0.69)\end{array}$ \\
\hline
\end{tabular}





Date Due 

. 